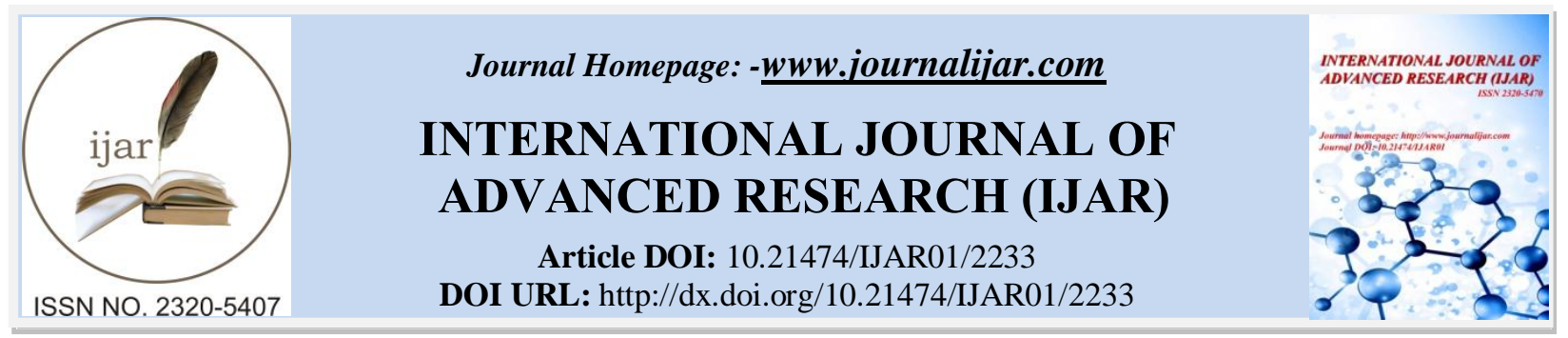

RESEARCH ARTICLE

\title{
RISK ASSESSMENT OF RADIONUCLIDES IN GROUNDWATER IN SIWA OASIS, EGYPT.
}

\section{Ibrahim H. Saleh ${ }^{1}$, Amira M. Elnaggar ${ }^{2}$ and Hesham Z. Ibrahim ${ }^{1}$.}

1. Department of Environmental Studies, Institute of Graduated Studies and Research, Alexandria University, Elhorrya Avenue 21526 P.O. Box 832 El-Shatby, Alexandria, Egypt.

2. General Management of Quality and central labs, Matrouh Water and Waste water Company, Holding Company of water and waste water, Matrouh, Egypt.

\section{Manuscript Info}

\section{Manuscript History}

Received: 29 September 2016

Final Accepted: 30 October 2016

Published: November 2016

Key words:-

Groundwater, Effective dose, Genetic risk, Siwa oasis. Radionuclides, Lifetime cancer risk,

\begin{abstract}
In this study eleven groundwater sources includes wells and springs in Siwa oasis, Egypt were subjected to radioactivity measurement and assessment during the period from June (2014) to July (2014). Siwa oasis located $65 \mathrm{~km}$ east of the Libyan frontier and $300 \mathrm{~km}$ south of the Mediterranean coast and around $800 \mathrm{~km}$ west Cairo. The collected water samples were acidified in the field then transferred to radiation measurement laboratory at Institute of Graduate Studies and Research, Alexandria University. The samples were prepared for gamma rays spectroscopic analysis by high purity germanium gamma rays spectrometer.

Radionuclides ${ }^{238} \mathrm{U},{ }^{226} \mathrm{Ra},{ }^{228} \mathrm{Ra},{ }^{40} \mathrm{~K}$ measurements were performed according to method of IAEA. The obtained radioactivity concentrations displayed ranges $(2.3-11.28) \mathrm{Bq} / \mathrm{L},(0.08-7.47) \mathrm{Bq} / \mathrm{L}$, $(0.472-4.1) \mathrm{Bq} / \mathrm{L}$, and $(0.0245-5.33) \mathrm{Bq} / \mathrm{L}$ for ${ }^{238} \mathrm{U},{ }^{226} \mathrm{Ra},{ }^{228} \mathrm{Ra}$ and $^{40} \mathrm{~K}$, respectively.

Radiological effects due to internal radiation exposure via drinking water from studied wells indicated annual effective doses ranged from $0.71 \mathrm{mSv} /$ year to $3.79 \mathrm{mSv} /$ year.

Lifetime cancer risk and genetic risk due to these radiation levels were calculated to be ranged from $2749 \times 10^{-6}$ to $14592 \times 10^{-6}$ and from $499 \times$ $10^{-6}$ to $2653 \times 10^{-6}$ for cancer risk and genetic risk, respectively.
\end{abstract}

Copy Right, IJAR, 2016,. All rights reserved.

\section{Introduction:-}

Siwa oasis represents the last virgin oasis in the western desert of Egypt ${ }^{(1)}$ Groundwater is the main source of water in the oasis ${ }^{(2)}$. Siwa is located above two great complex reservoirs of groundwater. The upper deposit is composed of interstitial water confined in the cavities of Miocene limestone extending down to depth of 50 to $700 \mathrm{~m}$ below the surface. The lower aquifer composed of thick layers of Nubian sandstone ${ }^{(2)}$. Groundwater in the Nubian Sandstone aquifer, hydrologically unsteady aquifer over the past thousands of years, is known to be fossil water and its abstraction is unrenewable ${ }^{(1)}$.

Many forms of "radiation" are encountered in the natural environment and are produced by modern technology ${ }^{(3)}$ Radionuclides generally enter drinking water through the erosion or chemical weathering of naturally occurring mineral deposits, although human activity (such as mining, industrial activities, or military activities that 
use or produce man-made radioactive materials) can also contribute to their presence in water ${ }^{(4)}$.Long-lived radioactive elements which occur naturally in water are $\mathrm{U}^{238}$ and $\mathrm{Th}^{232}$. Both uranium and thorium disintegrate slowly and produce other, intermediate radionuclides, such as radium, which in turn undergo still further radioactive decay $^{(5)}$.Radium emits alpha and beta radiation which is ionizing radiation. . If radium is ingested, especially dissolved in water, then the emitted alpha- and beta-particle radiation can come into contact with internal cell tissue and ionize and damage them. The risk incurred from the alpha-particle emissions depends on the way the body metabolizes the ingested radionuclide as said by Durrance, (1986).

\section{Experimental method:-}

Study area:-

Siwa Oasis is a depression located in the northern part of the Western Desert of Egypt. The area at Siwa depression is about $1100 \mathrm{Km}^{2}$ extending about $80 \mathrm{~km}$ from east to west ${ }^{(6)}$. The oasis located $65 \mathrm{~km}$ east of the Libyan frontier and $300 \mathrm{~km}$ south of the Mediterranean coast and around $800 \mathrm{~km}$ west Cairo.

Groundwater Samples were collected from seven deep artesian wells and three shallow wells and Cleopatra spring in Siwa oasis, where six wells are used for purpose of drinking and irrigation, one well is used for drinking and feed a station of drinking water production and for irrigation only three wells and a spring are used ${ }^{(6)}$. The sampling sites were chosen because they were the main source of drinking water and irrigation. Groundwater positions were illustrated on the map fig. 1 .

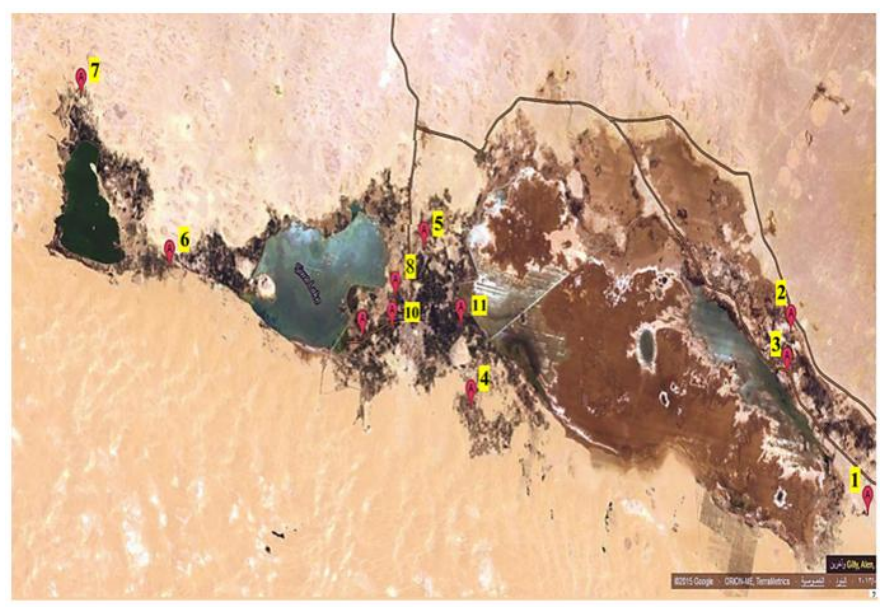

Fig. 1. Map of samples sites.

Those sites were selected by GPS (Global positioning system). Groundwater positions (Latitude and longitude), the site name and Codes found in Table 1.

Table 1:-Siwa oasis samples sites and codes

\begin{tabular}{|c|c|c|c|}
\hline Sample site & Code & Latitude & longitude \\
\hline Ainsafy & 1 & 29.13424534 & 25.799732 \\
\hline Abo shrof & 2 & 29.19554299 & 25.753486 \\
\hline Eldakrorelgeded & 3 & 29.18071 & 25.5564314 \\
\hline Eldakrorelkadeem & 4 & 29.1695115 & 25.5278112 \\
\hline Habbon & 5 & 29.22341 & 25.3716708 \\
\hline Gazalat & 6 & 29.2176020 & 25.3178531 \\
\hline Bahyeldeen & 7 & 29.27529151 & 25.5104588 \\
\hline Messos & 8 & 29.20714410 & 25.4902399 \\
\hline Kota & 9 & 29.19283910 & 25.5080594 \\
\hline Omar medany & 10 & 29.19622071 & 25.5500193 \\
\hline
\end{tabular}

\section{Sampling:-}

Eleven groundwater Samples were collected once during the period from June (2014) to July (2014), pumps of wells were turned on for $30 \mathrm{~min}$. Five liters were collected in polyethylene bottles from each site (well/spring) then 
acidified to $\mathrm{pH}<2$ then the collected samples were transported in ice box to the laboratory of Institute of Graduate Studies and Research, Alexandria University. Samples were refrigerated at $4^{\circ} \mathrm{c}$ until time of analysis.

\section{Samples preparation:-}

Samples were prepared by evaporation of each five-liter groundwater sample till reach one-liter, then transferred to counting container (Marinelli beakers with lids) of one-liter capacity for counting by the detector for $12 \mathrm{hr}$. ${ }^{238}$ Uactivity were measured by its daughter ${ }^{234} \mathrm{Th}$ at $63.29 \mathrm{keV}$ and $92.38 \mathrm{keV}$ as equilibrium established between ${ }^{238} \mathrm{U}$ and ${ }^{234} \mathrm{Th}$ in prepared groundwater samples after $6^{\text {th }}$ month.

\section{Radioactivity measurements:-}

Prepared samples were measured by High Purity Germanium gamma ray spectrometer (HPGe) model CS20A31CL. Liquid Nitrogen $\left(-196{ }^{\circ} \mathrm{C}\right)$, is used to cool the detector for operation. The data were gathered, stored and analyzed by using Multi Channel Analyzer (MCA) of 4096 channel.Background radiation in the laboratory was counting by non-sample detection then the obtained gamma spectra were subtracted from sample data. energy calibration of the detector was made by measuring certified gamma radiation standards sources of known energies $\left({ }^{60} \mathrm{Co},{ }^{137} \mathrm{Cs}\right.$ and $\left.{ }^{241} \mathrm{Am}\right) .{ }^{152} \mathrm{Eu}$ radiation certified standard has been used for efficiency calibration. For internal quality control requirements, reference water samples (MAPEP-13-MaW29) were analyzed during the measurements to confirm the calibration. Externally, the laboratory participates periodically in proficiency testing (PT) program (MAPEP) for radiation measurements.

The radioactivity of ${ }^{40} \mathrm{~K}$ was determined by using $1460.8 \mathrm{keV}$ gamma line. Lines $186.21 \mathrm{keV}, 351.92 \mathrm{keV}$ and $609.31 \mathrm{keV}$ were used for ${ }^{226} \mathrm{Ra}$ radioactivity determination. Lines $338.32 \mathrm{keV}, 911.21 \mathrm{keV}$ and $968.97 \mathrm{keV}$ were used for ${ }^{228} \mathrm{Ra}$ radioactivity determination. ${ }^{238} \mathrm{U}$ radioactivity was determined using $92.38 \mathrm{keV}$ and $63.29 \mathrm{keV}$ gamma lines. The minimum detectable activity (MDA) was calculated for each radionuclide according to Eq. (1).Levels of MDA were calculated based on the counting conditions used for measuring the studied groundwater samples and listed in Table 2.

$$
M D A=\frac{L_{D}}{T \times E f f(E) \times \rho_{\gamma}(E) \times V}(1)
$$

Where T, Eff(E), $\rho_{\gamma}(E), \mathrm{V}$ and $\mathrm{LD}$ are counting time, full energy peak efficiency at photon energy E, emission probability, volume of sample and the detection limit, calculated using next equation,

$$
L_{D}=L_{\mathrm{c}}+K_{\sigma_{D}}(2)
$$

Where Lc is critical level, below which no signal can be detected, $\sigma_{D}$ is standard deviation and $\mathrm{K}$ is error probability.

Table 2:-Minimum detectable activities (MDA) of measured radionuclides.

\begin{tabular}{|l|l|l|}
\hline Radionuclide & Gamma energy keV & MDA Bq/L \\
\hline${ }^{238} \mathrm{U}\left({ }^{234} \mathrm{Th}\right)$ & 92.38 & 0.018 \\
\hline${ }^{226} \mathrm{Ra}$ & 351.92 & 0.027 \\
\hline${ }^{228} \mathrm{Ra}\left({ }^{228} \mathrm{Ac}\right)$ & 338.32 & 0.18 \\
\hline${ }^{40} \mathrm{~K}$ & 1460.8 & 0.032 \\
\hline
\end{tabular}

\section{Radiological risk assessment:-}

The Annual Intake of Radioactivity (Bq/year).

WHO (2004) ${ }^{(7)}$ has estimated that $2 \mathrm{~L}$ is the average consumption of water in day by adults, giving an annual consumption of $730 \mathrm{~L}$ for each adult. Then the amount of each radionuclide ingested per year from the water supply is the concentration of that radioisotope in the water $(\mathrm{Bq} / \mathrm{L})$ multiplied by 730 . The annual intakes dose of detected radionuclides was calculated using equation 3.

\section{Annual Intake $(\mathrm{I})=$ Concentration of radionuclide in drinking water $(B q / L) \times$ Annual} Consumption of water $(L / y)$

Annual Effective Doses due to water consumption $\left(\mathrm{mSvy}^{-1}\right)$.

The annual effective dose was calculated with the intake of individual radionuclide and ingestion dose coefficients $\left(\mathrm{mSvBq}^{-1}\right)$ reported by the International Commission on Radiological Protection (ICRP) ${ }^{(8)}$.

The annual radiological dose for a person drinking water that contains a certain level of radioactivity is calculated by equation $4^{(9)}$ as follows: 


\section{Annual Effective Dose $(A E D)(m S v / y)=I \times D C F(m S v / B q)$}

Total Annual effective dose (total AED) per person is given by equation 3:

Total AED $=\Sigma\left(I_{i} \times D C F_{i}\right)$

Where $i$ is the radionuclide ${ }^{238} \mathrm{U},{ }^{226} \mathrm{Ra},{ }^{228} \mathrm{Ra},{ }^{40} \mathrm{~K}$.

\section{Radiological Risk Characterizations:-}

The risk incurred by the consumer is estimated by assuming linear dose-effect relationship with no threshold as per International commission on radiological protection (ICRP, 2008, WHO, 2011)practice. For low doses ICRP proposes nominal probability coefficient for detriment adjusted cancer risk as $5.5 \times 10^{-5} \mathrm{mSv}^{-1}$ for the whole population. The annual cancer risk was estimated using the following equation $6^{(7),(10)}$ :

Annual cancer risk $=$ total $\mathrm{AED}(\mathrm{mSv} / \mathrm{year}) \times$ cancer risk factor $\left(\mathrm{mSv} v^{-1}\right)$

\section{Results and discussion:-}

Radioactivity measurements

Uranium-238 $\left({ }^{238} \mathrm{U}\right)$

Levels of ${ }^{238} \mathrm{U}\left({ }^{234} \mathrm{Th}\right)$ radioactivity in ground water of Siwa oases varies from $2.3 \mathrm{~Bq} / \mathrm{L}$ to $11.28 \mathrm{~Bq} / \mathrm{L}$. the WHO $(2004){ }^{(14)}$ for water quality Standards has recommended $10 \mathrm{~Bq} / \mathrm{L}$ as the desirable limit. As shown in fig. 2.

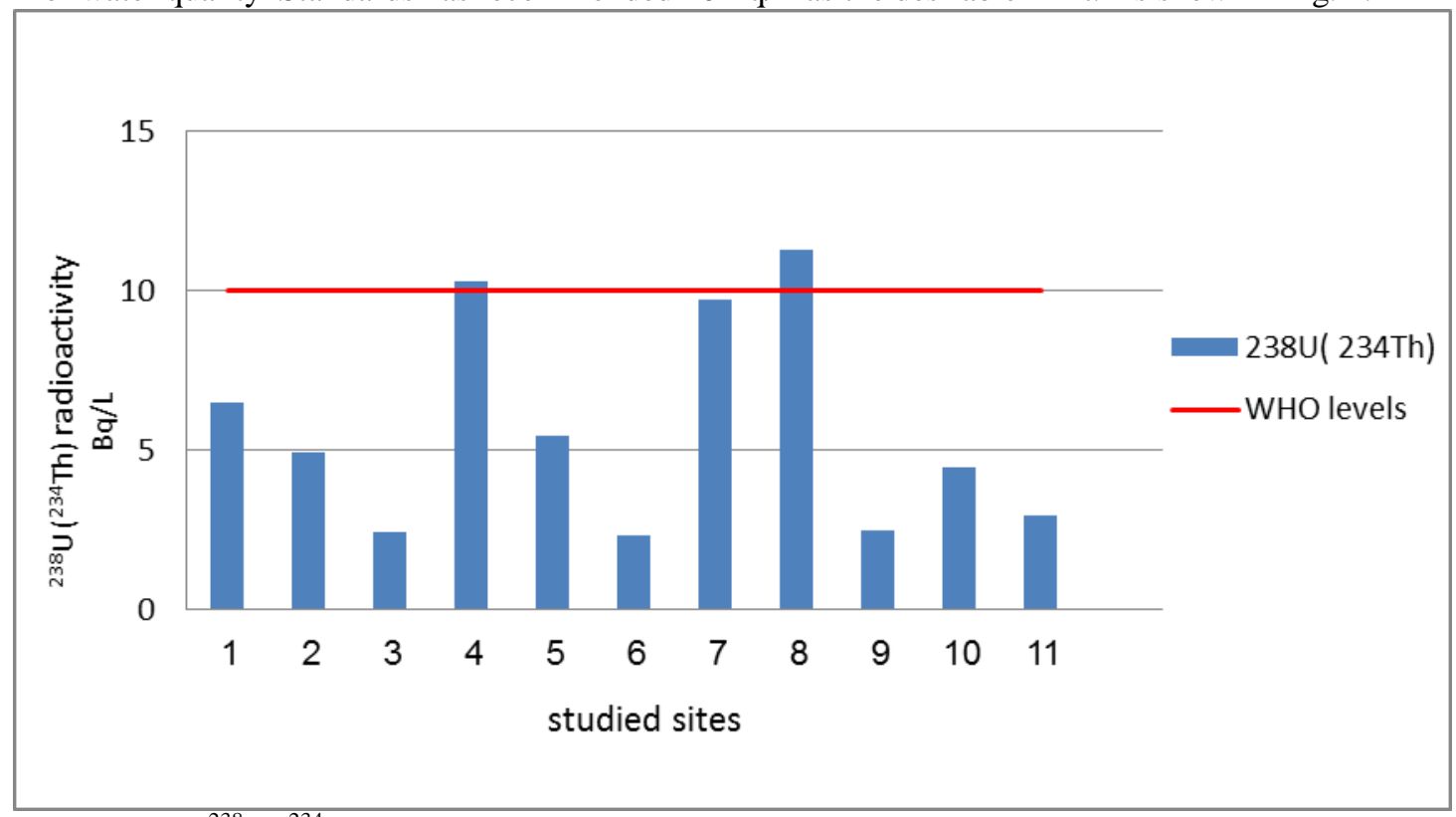

Fig. 3:-Levels of ${ }^{238} \mathrm{U}\left({ }^{234} \mathrm{Th}\right)$ radioactivity $(\mathrm{Bq} / \mathrm{l})$ in water samples collected from the studied locations. WHO limits $10 \mathrm{~Bq} / \mathrm{l}$

\section{Radium-226 ${ }^{226}$ Ra)}

The Levels of ${ }^{226} \mathrm{Ra}$ radioactivity in groundwater of Siwa oases varies from $0.08 \mathrm{~Bq} / \mathrm{L}$ to $7.47 \mathrm{~Bq} / \mathrm{L}$. the WHO $(2004)^{(14)}$ for water quality Standards has recommended $1 \mathrm{~Bq} / \mathrm{L}$ as the desirable limit. As shown in fig. 4. 


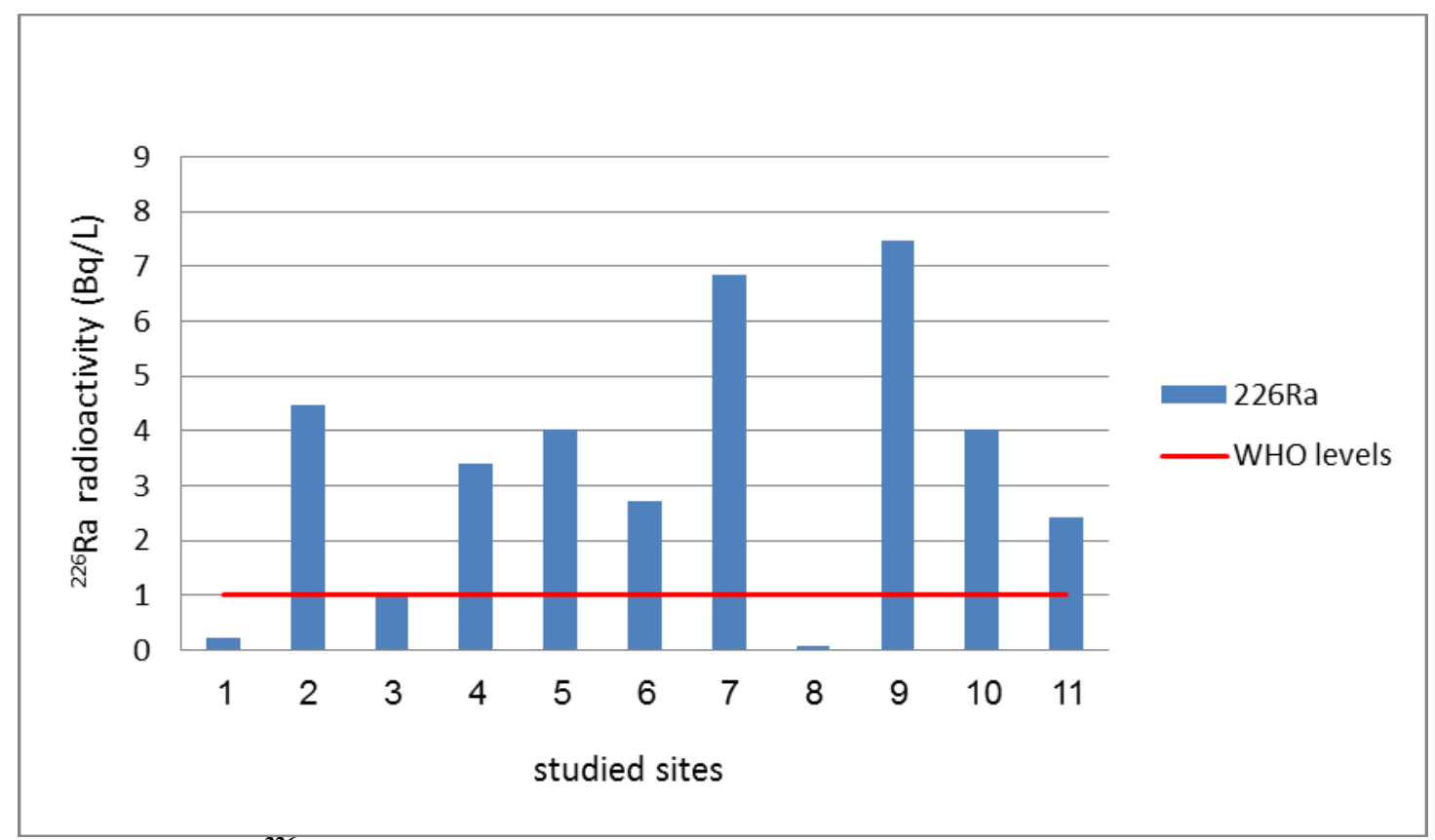

Fig. 4: Levels of ${ }^{226} \mathrm{Ra}$ radioactivity $(\mathrm{Bq} / \mathrm{L})$ in water samples collected from the studied locations. WHO limits $1 \mathrm{~Bq} / 1$

Radium-228 $\left({ }^{228}\right.$ Ra)

The Levels of ${ }^{228} \mathrm{Ra}$ radioactivity in groundwater of Siwa oases varies from $0.472 \mathrm{~Bq} / \mathrm{L}$ to $4.1 \mathrm{~Bq} / \mathrm{L}$. the WHO $(2004)^{(14)}$ for water quality Standards has recommended $0.1 \mathrm{~Bq} / \mathrm{L}$ as the desirable limit. As shown in fig. 5.

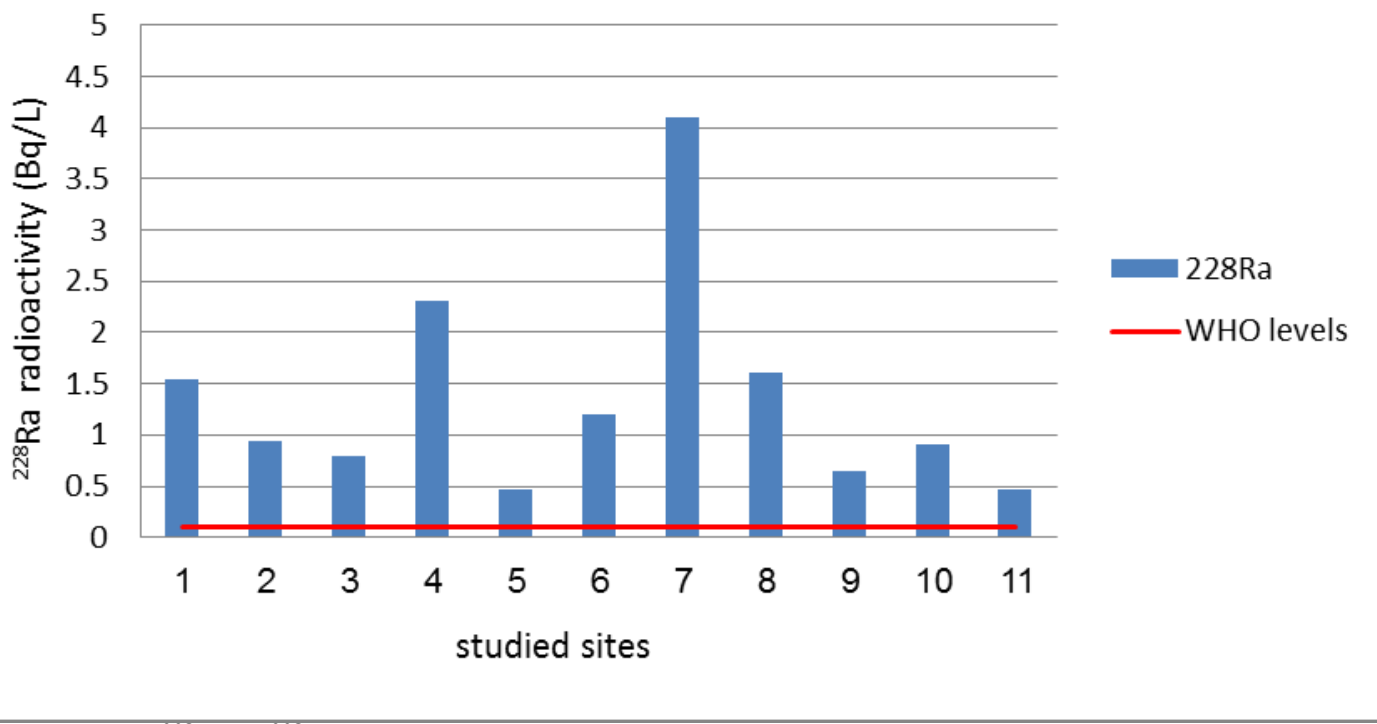

Fig. 5: Levels of ${ }^{228} \mathrm{Ra}\left({ }^{228} \mathrm{Ac}\right)$ radioactivity (Bq/L) in water samples collected from the studied locations.WHO limits $0.1 \mathrm{~Bq} / \mathrm{l}$

Potassium $\left({ }^{40} \mathrm{~K}\right)$

Levels of ${ }^{40} \mathrm{~K}$ radioactivity in groundwater of Siwa oases vary from $0.0245 \mathrm{~Bq} / \mathrm{L}$ to $5.33 \mathrm{~Bq} / \mathrm{L}$. Fig. 6 . 


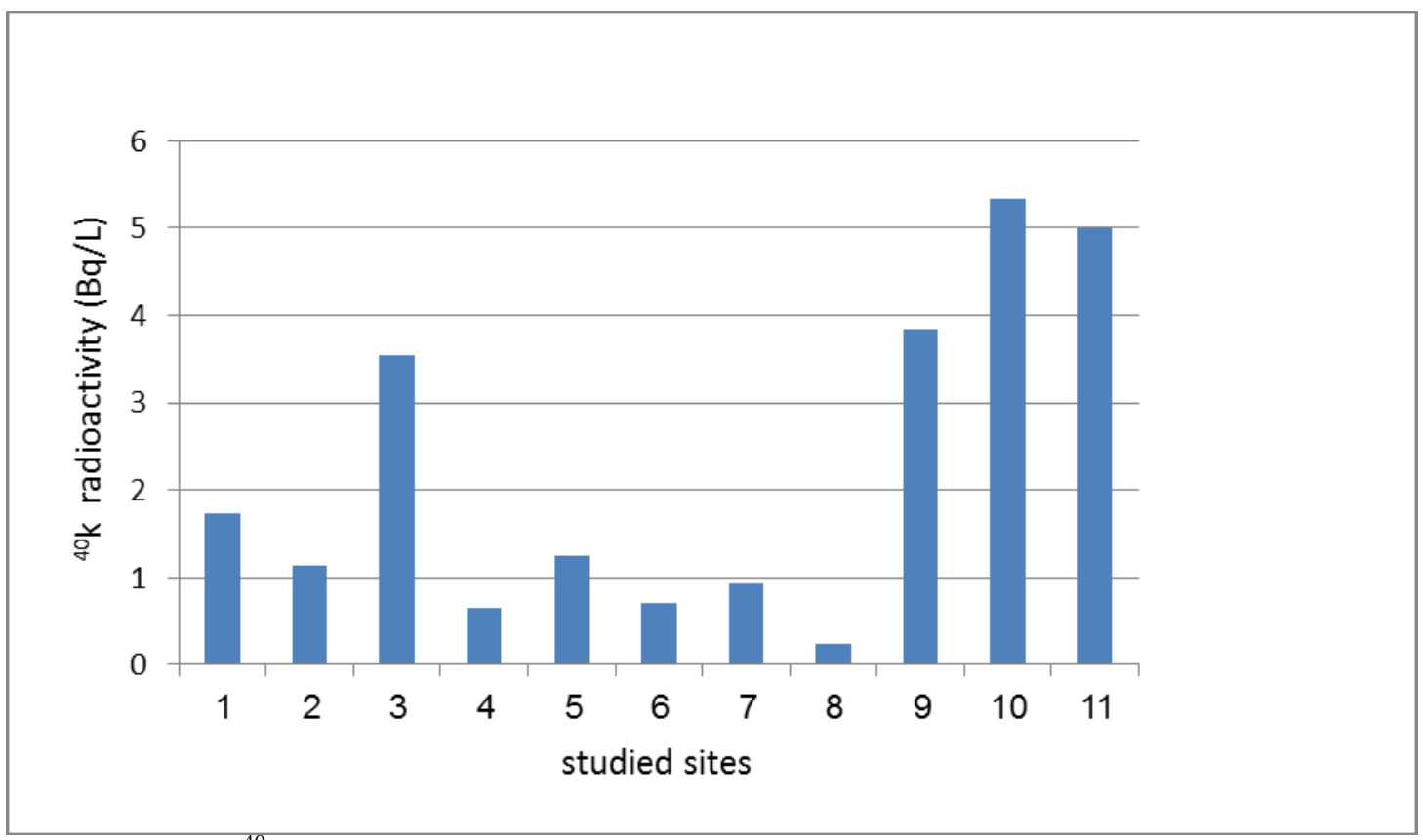

Fig. 6: Levels of ${ }^{40} \mathrm{~K}$ radioactivity $(\mathrm{Bq} / \mathrm{L})$ in water samples collected from the studied locations.

Radiological cancer risk assessment:-

Total annual effective dose:-

Total annual effective dose of radioactive nuclides in groundwater of Siwa oases varies from $0.71 \mathrm{mSv} / \mathrm{year}$ to 3.79 $\mathrm{mSv} /$ year. total Annual effective doses radiation during water consumption for all wells/springe in the study area are much higher than the reference level of the committed effective dose recommended by the WHO $\left(0.1 \mathrm{mSvy}^{-1}\right)$.As shown in fig. 7.

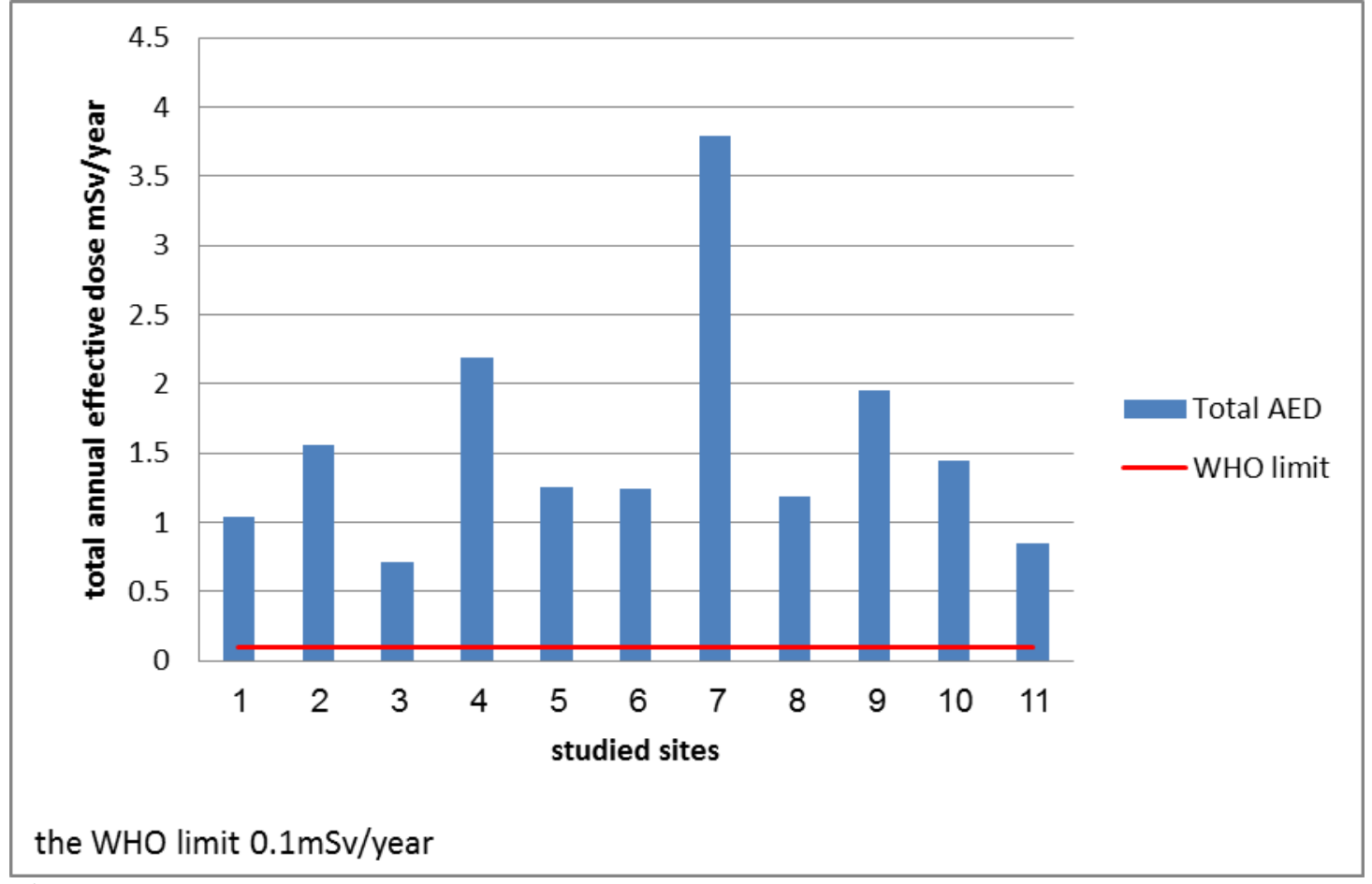

Fig. 7: Total annual effective dose (mSv/year) in water samples collected from the studied locations. 


\section{Annual cancer risk:-}

Annual cancer risk of radioactive nuclides in groundwater of Siwa oases varies from $39.27 \times 10^{-6}$ to $208.46 \times 10^{-6}$. WHO (2011) ${ }^{(37)}$ for water quality Standards has recommended $5.5 \times 10^{-6}$ as annual cancer risk. It is evident from results that about $100 \%$ of the samples exceed the desirable limit as shown in Fig. 8.

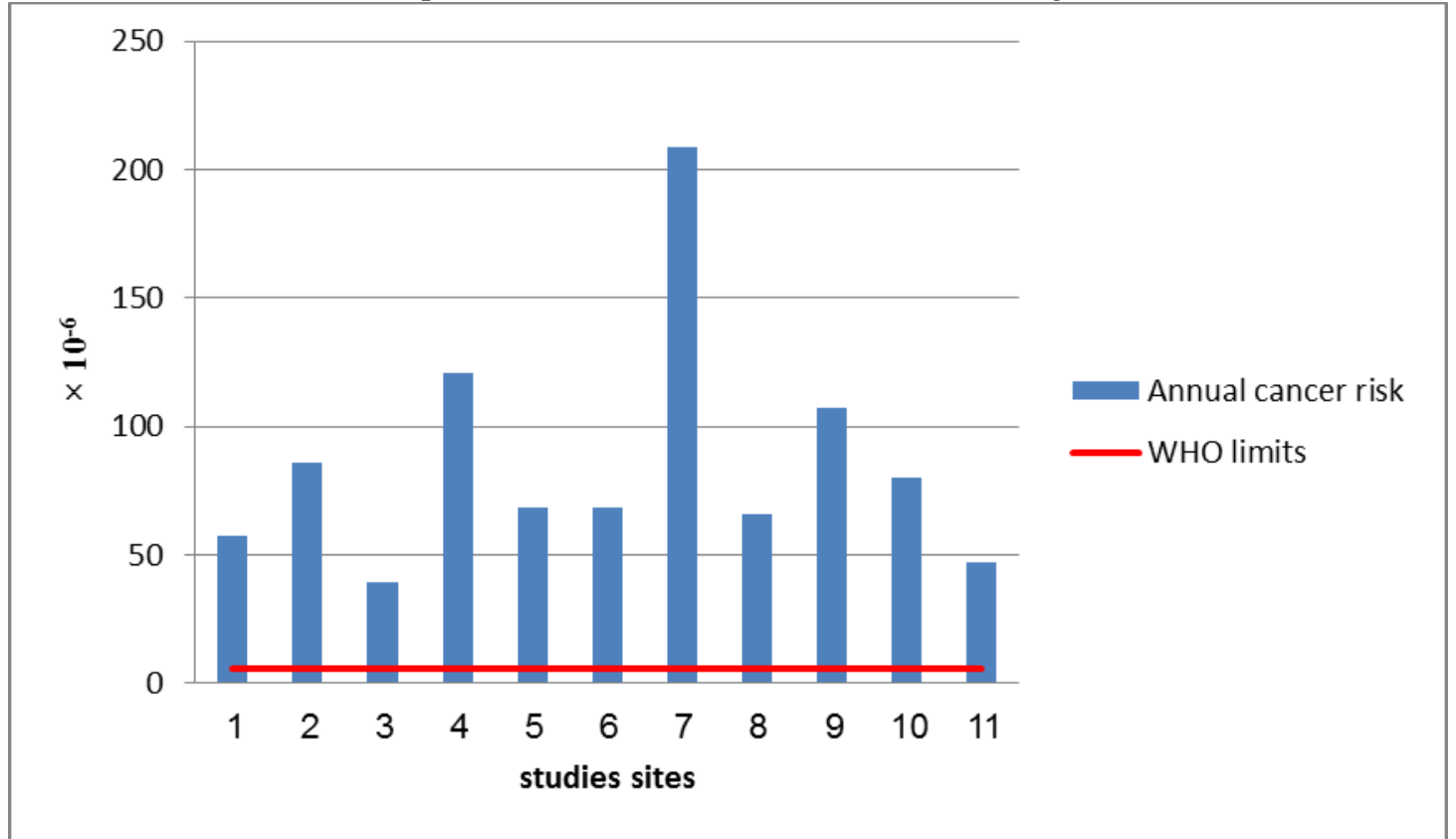

Fig. 8: Annual cancer risk in water samples collected from the studied locations. annual cancer risk $5.5 \times 10^{-6}$.

\section{Conclusions and Recommendations:-}

Results of the study of groundwater of siwa oasis have illustrated that:

Radionuclides radioactivity in ground water of Siwa oases were determined to vary from $2.3 \mathrm{~Bq} / \mathrm{L}$ to $11.28 \mathrm{~Bq} / \mathrm{L}$ for levels of ${ }^{238} \mathrm{U}\left({ }^{234} \mathrm{Th}\right),{ }^{226} \mathrm{Ra}$ radioactivity levels varied from $0.08 \mathrm{~Bq} / \mathrm{L}$ to $7.47 \mathrm{~Bq} / \mathrm{L}$, Levels of ${ }^{228} \mathrm{Ra}$ radioactivity varied from $0.472 \mathrm{~Bq} / \mathrm{L}$ to $4.1 \mathrm{~Bq} / \mathrm{L}$, and levels of ${ }^{40} \mathrm{~K}$ radioactivity varied from $0.0245 \mathrm{~Bq} / \mathrm{L}$ to $5.33 \mathrm{~Bq} / \mathrm{L}$.

Total annual effective dose of radioactive nuclides in groundwater of Siwa oases varied from $0.71 \mathrm{mSv} / \mathrm{year}$ to $3.79 \mathrm{mSv} /$ year.

Annual cancer risk of radioactive nuclides in groundwater of Siwa oases varies from $39.27 \times 10^{-6}$ to $208.46 \times 10^{-6}$.

Annual cancer risk of radioactive nuclides in groundwater was calculated to be high in study area due to high total annual intake of radioactive nuclides (emitting ionizing radiation).

As a consequence it was recommended to initiate a monitoring program for Siwa area, aiming to study the effect of pollution on the human health. An extensive survey is recommended to measure the level of radiation in the groundwater wells in Siwa. A treatment system or systems that remove the radionuclides that were detected above the maximum contaminant levels is recommended to reduce the cancer risk such as removal from groundwater by ion exchange resin ${ }^{(11)}$.

\section{References:-}

1. Abdulaziz, M.A. and Faid, M.A. (2013) Evaluation of the groundwater resources potential of Siwa Oasis using three-dimensional multilayer groundwater flow model, MersaMatruh Governorate, Egypt; springer.

2. Elkaffas, S.M.; Massoud A.M.; El-Raey, M. and El-Wakeel, H. (2013) Spatial Decision Support System for Water Wells Mining in Siwa Oasis; International Journal of Water Resources and Arid Environments.

3. Klasson, K.T. and Taylor, P.A.; Environmental and ecological chemistry; vol. III; Remediation of Groundwater Contaminated with Radioactive Compounds.

4. EPA (2002) Radionuclides in Drinking Water: A Small Entity Compliance Guide.

5. OEHHA (2006) Public health goals for radium-226 and -228 in Drinking Water. Office of Environmental Health Hazard Assessment, California Environmental Protection Agency. 
6. Aly, A.A.; Kishk, F.M.; Gaber, H.M. and Al-Omran, A.M. (2014) Long-term detection and hydrochemistry of groundwater resources in Egypt: Case study of Siwa Oasis; King Saud University; Journal of the Saudi Society of Agricultural Sciences.

7. WHO (2004)Guidelines for Drinking-water Quality; $3^{\text {rd }}$ Edition.

8. ICRP (2008) The 2007 recommendations of the International Commission on Radiological Protection, ICRP Publication 103. Annals of the ICRP, 37(2-4).

9. Radioactivity Dose Calculation and Water Quality Evaluation Guidance (2002) Department of water affairs and forestry

10. Atwia, M.G.; Abu-Heleika, M. M. and El-Horiny, M. M. (2013) Hydrogeochemical and vertical electrical soundings for groundwater investigations, Burg El-Arab area, Northwestern Coast of Egypt, Journal of African Earth Sciences $80,8-20$.

11. Lucius Cole, P.E.; Cirrincione, J.; Radium removal from groundwater by Ion Exchange Resin. Technical paper, Water Quality association. 